\title{
Surface ice and gap layers in Antarctic sea ice: highly productive habitats
}

\author{
Gerhard Kattner ${ }^{1, *}$, David N. Thomas ${ }^{2}$, Christian Haas ${ }^{1}$, Hilary Kennedy ${ }^{2}$, \\ Gerhard S. Dieckmann ${ }^{1}$
}

${ }^{1}$ Alfred Wegener Institute for Polar and Marine Research, Postfach 120161, 27515 Bremerhaven, Germany

${ }^{2}$ School of Ocean Sciences, University of Wales-Bangor, Menai Bridge, Anglesey LL59 5AB, Wales, UK

\begin{abstract}
Biogeochemical investigations of the upper layers of sea ice were made on layered summer ice floes collected from the Weddell Sea, Antarctica, from mid-February to March 1997. The surface layers had a clearly defined bottom layer immediately overlying a gap filled with seawater. Generally the gap covered rotten sea ice below. Using differences in algal biomass, mostly in the bottom layer of the surface ice overlying the gap, the floes were classified as low, moderate or high biomass. In addition, a floe with a re-frozen gap layer was studied. In the floes with the highest biomass, particulate organic carbon (POC) and nitrogen (PON) reached concentrations of up to $6000 \mu \mathrm{MC}$ and $600 \mu \mathrm{MN}$ in the bottom layer. In the upper part of the surface ice layer and the gap water, particulate and dissolved organic matter concentrations (POM, DOM) were clearly lower. High concentrations of POM were generally accompanied by high values of DOM although POM values generally exceeded DOM. All C and N contents of organic matter were significantly correlated. In gap waters, POM was low but still clearly higher than in the surrounding seawater, whereas DOM was in the range of seawater concentrations. Most POC/PON and C/chlorophyll a ratios pointed to an actively growing algae community, whereas the higher and more variable DOC/DON ratios reflected the various sources influencing DOM composition. Nitrate and silicate closely followed the signature of salinity, reaching in some gap water samples values similar to seawater concentrations. In some samples, in particular from the upper part of the surface ice layer, nitrate was totally exhausted. The distribution of the regenerated nutrients ammonium and phosphate was totally different from that of nitrate and silicate, reaching values of up to 15.9 and $9.08 \mu \mathrm{M}$, respectively. The bottom ice layer of the floe with the re-frozen gap layer had a high biomass similar to that of the high-biomass ice floe. DOC concentrations were lower, and DON maximum was not clearly linked with DOC maximum, but instead was associated with high ammonium and phosphate concentrations. The significant correlations between POM and DOM as well as between nitrate and silicate and between the regenerated nutrients ammonium and phosphate indicate that the gap-layer floes are semi-enclosed, highly productive habitats that still maintain high biomass during freezing. They are ubiquitous in the Antarctic pack-ice zone and important features that support high algae standing stocks.
\end{abstract}

KEY WORDS: Antarctic sea ice - Gap layers - Biogeochemistry · Particulate organic matter · Dissolved organic matter $\cdot$ Chlorophyll $a \cdot$ Nutrients

\section{INTRODUCTION}

Sea ice dominates the seasonal physico-chemical dynamics of the Southern Ocean: not only does ice have profound implications for ocean-atmosphere processes, global ocean circulation and climate processes, it also has controlling roles in the ecology of the
Southern Ocean on a wide-ranging scale from the plankton through to large mammals and underlying benthic communities (reviews by Brierley \& Thomas 2002, Dieckmann \& Hellmer 2003).

Estimation of the annual productivity of the sea ice flora remains inconclusive. Although estimates of production within the ice range up to $25 \%$ of the annual 
production of the sea ice-covered Southern Ocean, it is more likely that the value is in fact somewhat more modest at around $5 \%$ (Lizotte 2001, Arrigo 2003 and citations therein). Whatever the actual contribution, it is clear that the sea ice assemblages are a vital reserve for grazing zooplankton and nekton, not only as a food source but also as a supply of dietary supplements such as specific polyunsaturated fatty acids that are in high concentrations synthesised by sea ice algae and bacteria (Fahl \& Kattner 1993, Brierley \& Thomas 2002, Thomas \& Dieckmann 2002a). The flux of ice biota to the water column and underlying benthos upon ice melt are key to the dynamics of ice-edge blooms and seasonal growth of benthic organisms (reviewed by Leventer 2003).

In recent years the high productivity of surface sea ice assemblages and of gap layers close to the sea ice surface have been well documented. Snow loading and the formation of snow ice and superimposed ice leads to the formation of horizontal surface ice layers and underlying semi-continuous gap layers at or below the water level of sea ice floes (Eicken et al. 1994, Jeffries et al. 1997, Haas et al. 2001, Massom et al. 2001). These gap layers have been referred to as 'freeboard' layers and develop from infiltration layers during flood-freeze cycles or after superimposed ice formation (Garrison \& Buck 1991, Fritsen et al. 1998, 2001, Haas et al. 2001). They represent the highly dynamic processes at the ice surface of Antarctic sea ice during spring and summer.

Extensive algae standing stocks may develop in these surface habitats, especially during late spring and summer (Garrison \& Buck 1991, Ackley \& Sullivan 1994, Fritsen et al. 1994, 1998, 2001, Haas et al. 2001) as well as in autumn (Garrison et al. 2003). In fact, these assemblages are responsible for some of the highest algae standing stocks recorded for Antarctic pack ice (Syvertsen \& Kristiansen 1993, Garrison \& Mathot 1996, Thomas et al. 1998). Such features have been reported from throughout the Antarctic pack ice zone and are therefore a key habitat-type when considering seasonal ice productivity, and in particular when constructing meaningful sea ice productivity models (Fritsen et al. 2001, Lizotte 2001, Arrigo 2003).

In turn, the highly concentrated algal biomass can attract large numbers of grazers such as copepods which proliferate in situ or krill which migrate through the underlying ice to the surface ice layers, to feed on microbial assemblages (Garrison \& Buck 1991, Thomas et al. 1998, Schnack-Schiel et al. 2001). Not only are these surface habitats located where irradiance is high, but they are often associated with rotten, porous ice. This enables the exchange of inorganic nutrients that support extensive algal growth (Fritsen et al. 1998, 2001), although high rates of nutrient regeneration partly account for high algal growth in some cases (Thomas et al. 1998, Kennedy et al. 2002). These layered floes are semi-enclosed habitats with exceptional biological and chemical characteristics (Thomas et al. 1998). Although gap layers are clearly of ecological importance, there is relatively little information available regarding the biogeochemistry of these environments.

This work presents data on inorganic nutrients, dissolved organic matter and algal biomass parameters determined in surface ice layers and gap waters in the Weddell Sea during austral summer. Because floes were sampled at different locations and times, the data set is representative of different developmental stages of ice and related biological conditions during summer, including the re-freezing of gap layers at the transition from summer to autumn. The aim of the study was to examine different gap layer situations and investigate the biogeochemical characteristics of ice floes supporting different degrees of the standing stock of ice algae.

\section{MATERIALS AND METHODS}

Sampling. From mid-February to the beginning of March 1997, sea ice glaciological and biogeochemical investigations were performed during RV 'Polarstern' expedition ANT XIV/3 to the Weddell Sea, with particular focus on layered sea-ice floes in summer (see Fig. 1). Details of the cruise, sampling locations and ice conditions have been given by Haas et al. (1998) and on sampling and ice-coring by Haas et al. (2001) and Schnack-Schiel et al. (2001). Ice floes were sampled across the Weddell Sea along a transect from the SE at approximately $72^{\circ} \mathrm{S}, 20^{\circ} \mathrm{W}$ to the NW at $66^{\circ} \mathrm{S}, 56^{\circ} \mathrm{W}$ and back. As most floes were located within the Inner Marginal Ice Zone, they usually had diameters of less than $100 \mathrm{~m}$ with an ice cover of concentrations below $50 \%$ (Haas et al. 2001). General ice floe characteristics are given in Table 1.

Extensive biogeochemical investigations were performed on 5 floes. Ice cores were taken along transects from the edge of each floe towards its centre in an effort to include variability in biogeochemical parameters between floes and as a function of distance from the floe edge, where exchange with seawater would be expected to be highest. At each sampling point, both surface ice and gap waters were sampled. Surface ice cores (10 cm diameter) were drilled manually down to the underlying gap layer. Care was taken to ensure that the integrity of the bottom ice directly overlying the gap was maintained, and that gap waters did not contaminate the ice samples. The thickness of surface ice layers was generally less than $20 \mathrm{~cm}$, except at 2 locations where it was 26 and $36 \mathrm{~cm}$. The layers were immediately cut into vertical sections of 3 to $10 \mathrm{~cm}$ (mostly between 4 and $6 \mathrm{~cm}$ thick) with a clean stainless-steel saw. After sectioning, the ice samples were 
placed in $1 \mathrm{dm}^{3}$ opaque PVC containers. The gap waters were sampled with clean glass syringes and/or $50 \mathrm{ml}$ clean glass bottles, depending on the size of the gap layer. The collected waters were then passed through a sieve (mesh size $200 \mu \mathrm{m}$ ) to remove ice crystals, slush and larger organisms. The ice underlying the gaps was rotten, and mostly too brittle and fragile to be sampled by standard coring techniques. Therefore, for the purpose of this study, the ice under the gap layer is not considered.

The 4 floes with the gap layer were classified as low, moderate or high biomass according to the contents of particulate organic matter (POC, PON) and chlorophyll $a(\mathrm{chl} a)$ in the surface ice layer, especially in the bottom section; this classification also applied to dissolved organic matter (DOC, DON) (see Table 2) contents. In addition, data for a fifth floe with a re-frozen gap is presented. The 'low biomass floe' was sampled on 22 February at $68^{\circ} 38^{\prime} \mathrm{S}, 44^{\circ} 41^{\prime} \mathrm{W}$; 4 ice cores were drilled $0.5,2.5,4$ and $6 \mathrm{~m}$ away from the floe edge. The moderate biomass floe' was sampled on 24 February at $69^{\circ} 43^{\prime} \mathrm{S}, 40^{\circ} 34^{\prime} \mathrm{W}$; 4 ice cores were drilled $0,1,2$ and $3 \mathrm{~m}$ away from the floe edge. We sampled 2 high biomass floes on 28 February and 1 March, at $72^{\circ} 14^{\prime} \mathrm{S}$, $33^{\circ} 09^{\prime} \mathrm{W}$ and $71^{\circ} 59^{\prime} \mathrm{S}, 26^{\circ} 01^{\prime} \mathrm{W}$, respectively; on the first floe, 3 cores were taken 36,37 and $38 \mathrm{~m}$ away from the floe edge; on the second floe, 2 cores were drilled $2 \mathrm{~m}$ apart in the middle of the floe. The re-frozen gap floe' was sampled on 26 February at $72^{\circ} 30^{\prime} \mathrm{S}, 35^{\circ} 52^{\prime} \mathrm{W}$; 8 cores were taken $1,3,5,7,9,11,13$ and $15 \mathrm{~m}$ away from the floe edge. On this floe it was clear that the gap layer had begun to freeze, with significant dendritic ice growth visible from the bottom of the surface ice growing downwards into the underlying gap water layer (see Fig. 1; also Haas et al. 2001).

The low- and moderate-biomass floes reflected early summer conditions, the high-biomass floes and the refrozen floe were typical of late summer and early autumn conditions, respectively.

Sample processing and analyses. On board ship, the ice sections were melted in the containers at $4^{\circ} \mathrm{C}$ in the dark.
This process took no longer than $24 \mathrm{~h}$ due to the porous nature of the ice. The gap water was processed immediately on return to the ship (i.e. $<5 \mathrm{~h}$ after collection).

Salinity of melted ice cores and gap waters was measured using a conductivity meter (WTW, Germany). All samples were filtered through precombusted GF/F filters (Whatman, $450^{\circ} \mathrm{C}, 3 \mathrm{~h}$ ). Samples for the determination of chl $a, \mathrm{POC}$ and PON concentrations were collected on filters and stored frozen at $-20^{\circ} \mathrm{C}$ until analysis in the home laboratories. Filtrates were poisoned with $\mathrm{HgCl}_{2}$ and stored at $4^{\circ} \mathrm{C}$ in $50 \mathrm{ml}$ concentration bottles for later inorganic nutrient and dissolved organic nitrogen (DON) contents (Kattner 1999). Additional filtrate samples were stored frozen (unpoisoned) in $50 \mathrm{ml}$ precombusted $\left(450^{\circ} \mathrm{C}, 3 \mathrm{~h}\right)$ glass ampoules for later dissolved organic carbon (DOC) determination.

Chl a was determined using a Turner fluorometer, after overnight extraction in $90 \%$ acetone in the dark at $4^{\circ} \mathrm{C}$ (Evans et al. 1987). Inorganic nutrients (nitrate, nitrite, silicate, ammonium, phosphate) were determined according to standard methods for seawater with an AutoAnalyzer (Bran \& Luebbe, Germany) as described by Kattner \& Becker (1991). Nutrients were measured a few months after sampling. Poisoning with $\mathrm{HgCl}_{2}$ has almost no effect on the determination of the major nutrients, nitrate, silicate and phosphate. Nitrite values are more variable but concentrations are generally very low in seawater. Ammonium values increased slightly by about $0.5 \mu \mathrm{M}$ during long-term storage and data had to be carefully checked (Kattner 1999). Because of the high concentrations in the ice sections, possible difference are negligible. DON was analysed following persulphate wet oxidation (Koroleff 1983), and DOC by high temperature oxidation using an MQ1001 TOC analyser (Qian \& Mopper 1996).

Filters for POC and PON were acid-fumed (concentrated $\mathrm{HCl}$ ) overnight to remove carbonate, dried at $40^{\circ} \mathrm{C}$ and then stored in a desiccator prior to analysis. POC and PON concentrations were determined with a Europa Scientific CHN analyser, using acetanilide as a standard.

Table 1. Mean characteristics of sampled ice floes. Ice thickness $\left(Z_{\mathrm{i}}\right)$ and snow thickness $\left(Z_{\mathrm{s}}\right)$ determined by electromagnetic thickness profiling across the entire floe; surface layer thickness $\left(Z_{\mathrm{sl}}\right)$ and gap width $\left(Z_{\text {gap }}\right)$ are mean values of surface core profiles. Note: all first-year floes had survived summer season and were in transition to second-year ice

\begin{tabular}{|c|c|c|c|c|c|c|c|c|c|c|}
\hline $\begin{array}{l}\text { Date } \\
\text { (1997) }\end{array}$ & $\begin{array}{l}\text { Biomass } \\
\text { classification }\end{array}$ & $\begin{array}{l}\text { Latitude } \\
{ }^{\circ} \mathrm{S}\end{array}$ & $\begin{array}{c}\text { Longitude } \\
{ }^{\circ} \mathrm{W}\end{array}$ & $\begin{array}{l}\text { Diameter } \\
\text { (m) }\end{array}$ & $\begin{array}{c}Z_{\mathrm{i}} \\
(\mathrm{m})\end{array}$ & $\begin{array}{c}Z_{\mathrm{s}} \\
(\mathrm{m})\end{array}$ & $\begin{array}{l}Z_{\mathrm{sl}} \\
(\mathrm{m})\end{array}$ & $\begin{array}{l}Z_{\text {gap }} \\
(\mathrm{cm})\end{array}$ & Description & Ice type \\
\hline $22 \mathrm{Feb}$ & Low & $68^{\circ} 38^{\prime}$ & $44^{\circ} 41^{\prime}$ & 150 & 0.37 & 0.07 & 0.13 & 2.3 & Lightly ridged & First-year \\
\hline $24 \mathrm{Feb}$ & Moderate & $69^{\circ} 43^{\prime}$ & $40^{\circ} 34^{\prime}$ & 60 & 4.14 & 0.58 & 0.15 & 15.0 & Heavily ridged & Second-year \\
\hline $28 \mathrm{Feb}$ & High & $72^{\circ} 30^{\prime}$ & $33^{\circ} 09^{\prime}$ & 35 & 1.25 & 0.17 & 0.20 & 9.0 & Flat floe & First-year \\
\hline 1 Mar & High & $71^{\circ} 59^{\prime}$ & $26^{\circ} 01^{\prime}$ & 50 & 3.41 & 0.15 & 0.19 & 18.0 & Ridged floe ${ }^{a}$ & First-year \\
\hline 26 Feb & Re-frozen gap & $72^{\circ} 30^{\prime}$ & $35^{\circ} 52^{\prime}$ & $>2000$ & 0.49 & 0.09 & 0.16 & 0.5 & Ridged floe & First-year \\
\hline
\end{tabular}




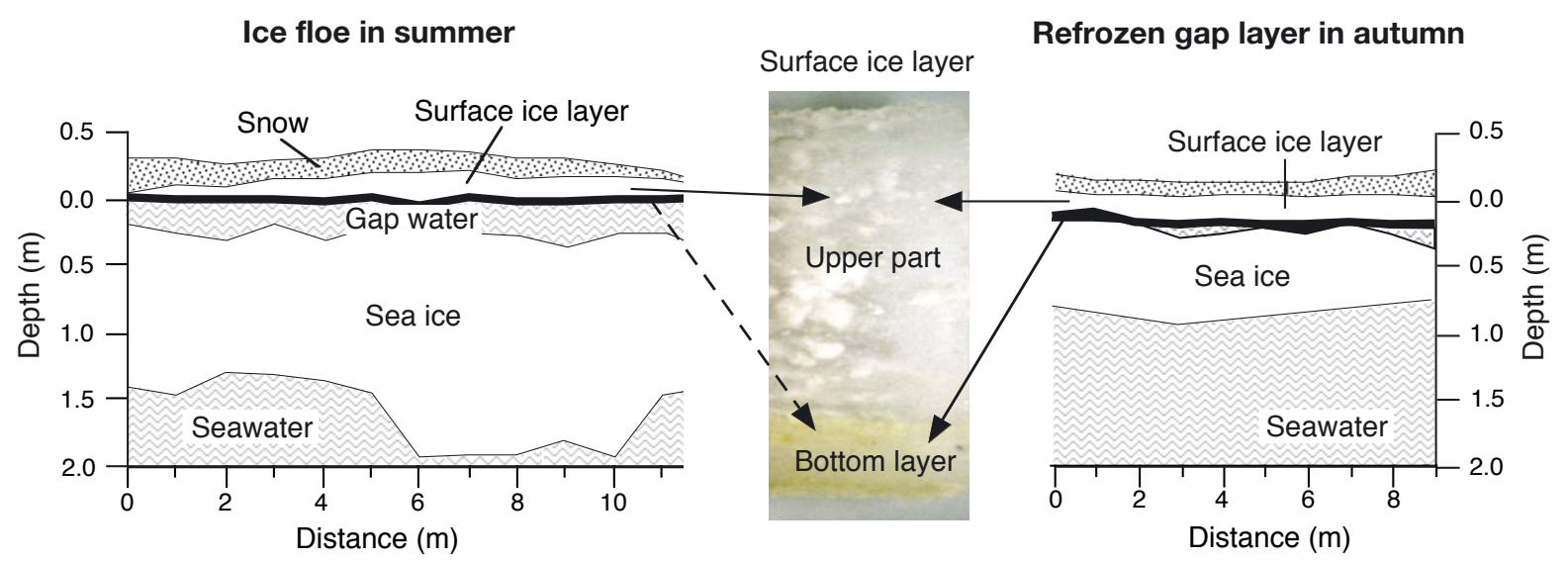

Fig. 1. Schematic vertical cross-sections of 2 ice floes with surface ice layers, one with a seawater-filled gap and underlying rotten sea ice, the other with a re-frozen gap-layer floe (modified after Haas et al. 2001). Water level is $0 \mathrm{~cm}$. Photograph shows vertical section of surface ice layer from re-frozen gap-layer floe; whole section is $14 \mathrm{~cm}$ deep, and bottom, greenish $3 \mathrm{~cm}$ is re-frozen gap layer supporting high algae standing stocks

\section{RESULTS}

\section{Floes with surface ice layer and underlying open gap}

Samples were divided into 3 different vertical zones: upper and bottom sections of the surface ice layer, and the gap below (Fig. 1). The thickness of the surface ice ranged from 13 to $20 \mathrm{~cm}$, except for 2 cores with 26 and $36 \mathrm{~cm}$ surface ice. The surface ice layer was mainly composed of superimposed ice; consequently, salinity was very low in the upper sections, increasing towards the bottom (Haas et al. 2001). It is probable that many surface ice layers consisted of snow ice at the bottom. The surface ice layer floated well in the water, i.e. the bottom of the surface ice was between 8 and $23 \mathrm{~cm}$ below sea level. The underlying gaps were typically 1 to $9 \mathrm{~cm}$ thick (Haas et al. 2001). The salinity of the gap waters was close to but below that of seawater (27 to 31 ).

Table 2. Range of particulate and dissolved constituents in surface ice layer of ice floes with open gap layers containing low, moderate and high biomass. (For individual data see Fig. 2)

\begin{tabular}{|c|c|c|c|c|c|c|c|}
\hline Constituent & Low & $\begin{array}{l}\text { Biomass } \\
\text { Moderate }\end{array}$ & High & Constituent & \multicolumn{3}{|c|}{ Biomass } \\
\hline \multicolumn{4}{|c|}{ Upper section of surface ice layer } & \multicolumn{4}{|c|}{ (Bottom section, continued) } \\
\hline Salinity & $3.3-6.1$ & $1.0-8.7$ & $0.9-8.8$ & $\mathrm{DON}(\mu \mathrm{M})$ & $20.1-29.3$ & $13.0-30.4$ & $47.4-65.3$ \\
\hline POC $(\mu \mathrm{M})$ & $72.7-126$ & $204-1082$ & $120-784$ & DOC/DON & $4.4-6.8$ & $4.3-15.6$ & $11.2-20.5$ \\
\hline PON $(\mu \mathrm{M})$ & $13.1-20.0$ & $24.9-137$ & $9.9-77.4$ & Nitrate $(\mu \mathrm{M})$ & $0.73-3.56$ & $2.80-8.12$ & $0.16-1.08$ \\
\hline $\mathrm{POC} / \mathrm{PON}$ & $5.6-6.3$ & $6.8-8.2$ & $8.0-12.2$ & Silicate $(\mu \mathrm{M})$ & $6.58-12.13$ & $8.11-20.43$ & $10.99-24.32$ \\
\hline Chl a $\left(\mu g l^{-1}\right)$ & $4.1-9.2$ & $5.5-178$ & $0.6-44.4$ & Ammonium $(\mu \mathrm{M})$ & $2.38-4.38$ & $3.78-9.38$ & $5.04-15.60$ \\
\hline $\mathrm{C} / \mathrm{chl} a$ & $120-294$ & $73-449$ & $172-557$ & Phosphate $(\mu \mathrm{M})$ & $1.09-1.42$ & $2.21-9.08$ & $3.60-8.72$ \\
\hline DOC $(\mu \mathrm{M})$ & $33-111$ & $\begin{array}{c}76-204 \\
188-373\end{array}$ & $\begin{array}{c}135-504 \\
94-379\end{array}$ & Gap water & & & \\
\hline $\begin{array}{l}\text { DON }(\mu \mathrm{M}) \\
\mathrm{DOC} / \mathrm{DON}\end{array}$ & $\begin{array}{l}9.3-20.6 \\
3.5-5.4\end{array}$ & $\begin{array}{c}18.8-37.3 \\
4.0-7.9\end{array}$ & $\begin{array}{l}9.4-37.9 \\
7.3-29.0\end{array}$ & Salinity & $31.2-31.3$ & $27.1-30.2$ & $30.6-31.0$ \\
\hline Nitrate $(\mu \mathrm{M})$ & $0.24-1.44$ & $0.66-6.76$ & $0.01-0.94$ & POC $(\mu \mathrm{M})$ & $21.4-48.0$ & $240-412$ & $42.9-177$ \\
\hline Silicate $(\mu \mathrm{M})$ & $3.24-8.82$ & $1.09-15.96$ & $0.29-4.47$ & PON $(\mu \mathrm{M})$ & $4.0-8.6$ & $32.1-61.5$ & $6.6-23.5$ \\
\hline Ammonium $(\mu \mathrm{M})$ & $0.98-2.27$ & $2.00-10.08$ & $0.76-4.57$ & $\mathrm{POC} / \mathrm{PON}$ & $5.4-7.1$ & $6.7-7.5$ & $6.4-7.5$ \\
\hline Phosphate $(\mu \mathrm{M})$ & $0.26-2.48$ & $1.98-3.43$ & $0.08-0.71$ & Chl $a\left(\mu g l^{-1}\right)$ & $1.3-4.1$ & $26.7-48.7$ & $3.1-16.5$ \\
\hline \multicolumn{4}{|c|}{ Bottom section of surface ice layer } & $\mathrm{C} / \mathrm{chl} a$ & $112-446$ & $85-134$ & $129-164$ \\
\hline Salinity & $8.5-11.2$ & $5.7-10.1$ & $10.7-12.5$ & $\mathrm{DOC}(\mu \mathrm{M})$ & $60-63$ & $63-92$ & $58-100$ \\
\hline POC $(\mu \mathrm{M})$ & $484-505$ & $292-1078$ & $955-6014$ & DON $(\mu \mathrm{M})$ & $5.4-8.7$ & $8.1-19.3$ & $7.7-19.1$ \\
\hline PON $(\mu \mathrm{M})$ & $70.2-78.9$ & $45.6-129$ & $123-580$ & DOC/DON & $7.3-11.4$ & $6.6-11.4$ & $5.2-8.4$ \\
\hline $\mathrm{POC} / \mathrm{PON}$ & $6.4-8.0$ & $6.1-8.4$ & $7.7-10.4$ & Nitrate $(\mu \mathrm{M})$ & $26.5-27.0$ & $23.3-25.9$ & $16.0-17.6$ \\
\hline Chl $a\left(\mu g l^{-1}\right)$ & $23.5-43.9$ & $41.4-247$ & $106-439$ & Silicate $(\mu \mathrm{M})$ & $69.0-69.6$ & $59.7-62.9$ & $48.4-68.5$ \\
\hline $\mathrm{C} / \mathrm{chl} a$ & $137-247$ & $52-82$ & $108-256$ & Ammonium $(\mu \mathrm{M})$ & $0.73-0.91$ & $1.14-1.81$ & $0.42-2.76$ \\
\hline $\mathrm{DOC}(\mu \mathrm{M})$ & $96-152$ & $70-203$ & $437-1339$ & Phosphate $(\mu \mathrm{M})$ & $1.79-2.11$ & $1.90-2.44$ & $1.08-1.32$ \\
\hline
\end{tabular}



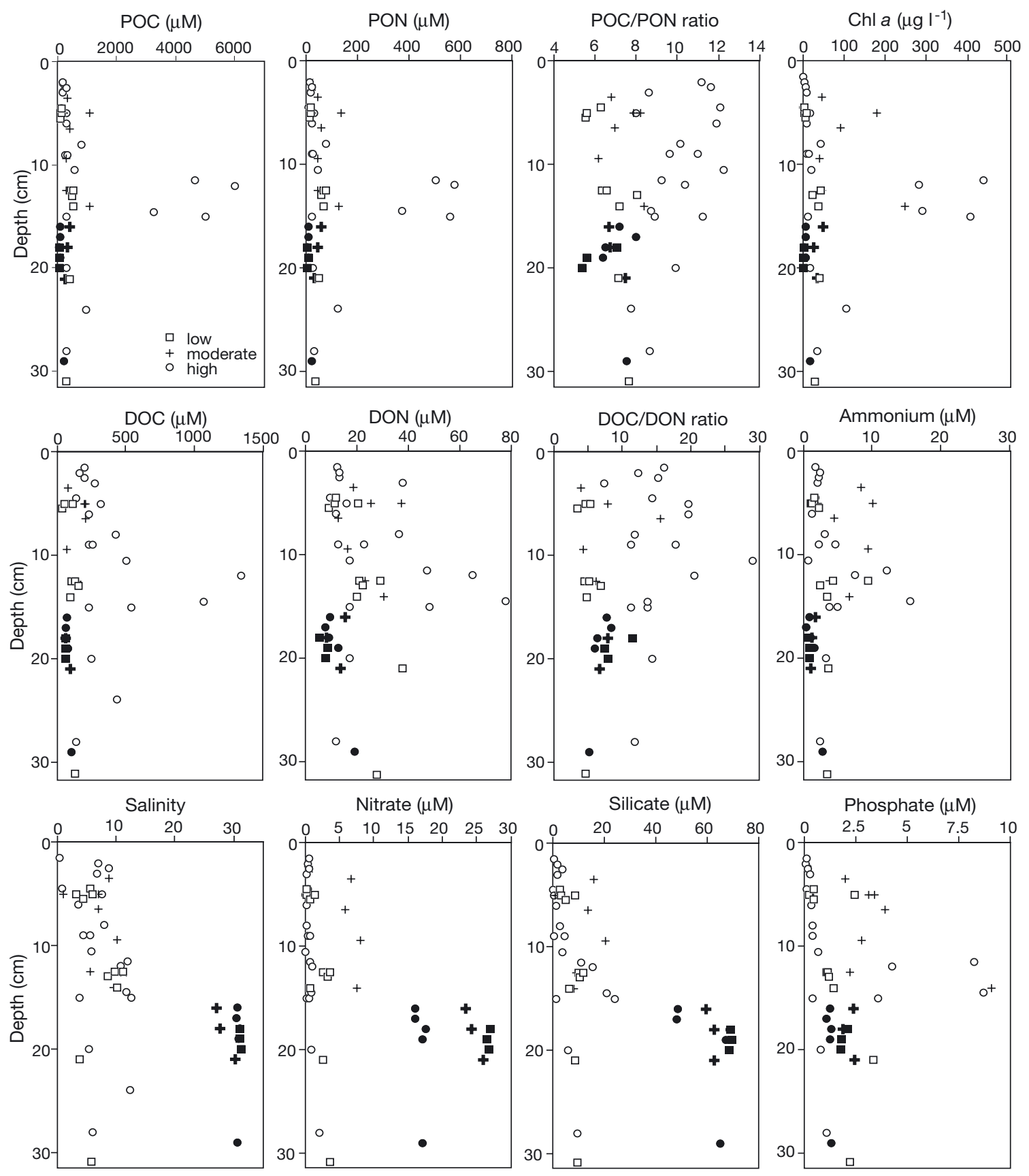

Phosphate $(\mu \mathrm{M})$

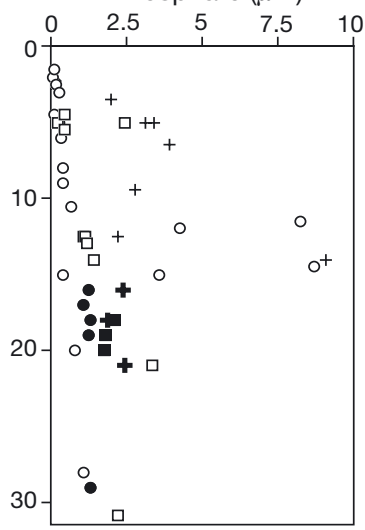

Fig. 2. Surface ice layer of ice floes with open gap layer. Profiles of particulate and dissolved constituents of ice layers (open symbols) and gap water (black symbols)

In all cores the bottom section of the surface ice generally had the highest concentrations of chl $a$, POM and DOM. Gap waters were characterised by high nitrate and silicate concentrations, in contrast to the surface ice in which both were mostly low. Data from the different surface ice layers and gap waters are presented in Fig. 2 and the range of values in Table 2.

In the high-biomass floes, POC concentrations reached maximum values of between 3000 and $6000 \mu \mathrm{M}$ in the bottom section of the surface ice. Minimum values for the bottom section $(955 \mu \mathrm{M})$ were recorded in the core with thick surface ice $(26 \mathrm{~cm})$. In the upper part of these cores, POC was still high (up to $784 \mu \mathrm{M}$ ), whereas in the gap water only low POC values between 43 and $177 \mu \mathrm{M}$ were found.

In the moderate-biomass floe, the range of POC concentrations was almost identical in both the upper and bottom sections of the surface ice, with values ranging 
from $\sim 200$ to $\sim 1100 \mu \mathrm{M}$. Concentrations from 240 to $412 \mu \mathrm{M}$ were found in the gap water - the highest measured in any of the gap-layer waters sampled.

In the low-biomass floe, the highest POC values of $\sim 500 \mu \mathrm{M}$ occurred again in the bottom section. The upper section contained concentrations of up to only $100 \mu \mathrm{M}$, and the gap-water POC concentrations were the lowest measured, ranging from 21 to $48 \mu \mathrm{M}$.

The distribution of PON was similar to that of POC as confirmed by a highly significant correlation $\left(r^{2}=0.9766, p<0.001, n=78\right.$, all data; Fig. 3$)$ and relatively constant molar $\mathrm{C} / \mathrm{N}$ ratios of the particulate material. All $\mathrm{C} / \mathrm{N}$ ratios were $<8.5$, except for the highbiomass floes, for which values of 12.2 and 10.4 were found in the upper part and bottom sections of the surface ice, respectively. In the gap water, the ratio was fairly constant in all floe categories, varying from 5.4 to 7.5 .

The close relationship between chl a concentrations and POC and PON was confirmed by the highly significant correlations (with POC: $\mathrm{r}^{2}=0.8463, \mathrm{p}<0.001, \mathrm{n}=77$; with PON: $\mathrm{r}^{2}=0.9017, \mathrm{p}<0.001, \mathrm{n}=77$ ). Chl $a$ was lower in the upper section of the surface ice and in the gap water. Highest values occurred in the bottom section, reaching up to $439 \mu \mathrm{g} \mathrm{l}^{-1}$ in the in the high-biomass ice floe. The $\mathrm{C} / \mathrm{chl}$ a ratio ( $\mu \mathrm{g}$ basis) was generally higher in the upper (73 to 557) than in the bottom (52 to 256) sections. In the gap waters of the moderate- and highbiomass floes, the ratios were still lower, varying be-
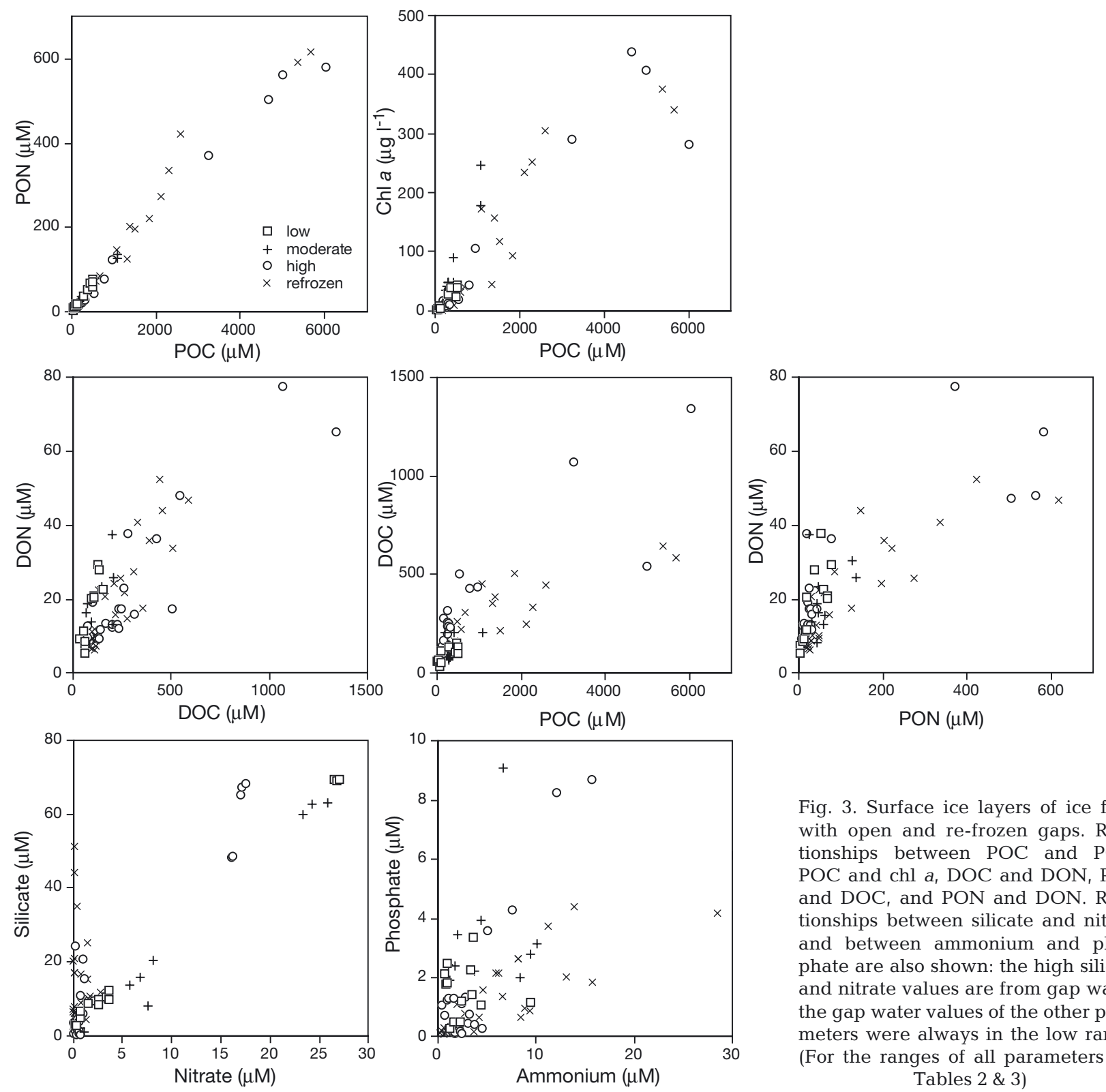

Fig. 3. Surface ice layers of ice floes with open and re-frozen gaps. Relationships between $\mathrm{POC}$ and $\mathrm{PON}$, POC and chl $a$, DOC and DON, POC and DOC, and PON and DON. Relationships between silicate and nitrate and between ammonium and phosphate are also shown: the high silicate and nitrate values are from gap water; the gap water values of the other parameters were always in the low range. (For the ranges of all parameters see Tables 2 \& 3) 
tween 85 and 164, whereas in the low-biomass floe the ratios were higher and more variable. The ratios show that the bulk of this particulate material was algae.

The concentrations of DOC ranged from $33 \mu \mathrm{M}$ in the upper section of the low-biomass floe to $1340 \mu \mathrm{M}$ in the bottom section of the high-biomass floes. In the samples with higher biomass, DOC concentrations were up to 5 times lower than those of POC. In the ice of the low-biomass cores, the lowest values $(33 \mu \mathrm{M})$ were even below typical Antarctic surface seawater concentrations (concentrations between 50 and $100 \mu \mathrm{M}$; e.g. Wedborg et al. 1998). In the gap water of all floes, DOC was relatively low, varying between 58 and $100 \mu \mathrm{M}$, which is comparable to surface concentrations in Weddell Sea seawater. The distribution of DON was similar to that of DOC, with the highest DON value of $77.7 \mu \mathrm{M}$ also found in the bottom section of the highbiomass floes and the lowest values associated with the gap water. DOC/DON ratios ranged from $\sim 4$ to 29 , and varied more strongly than POC/PON ratios. This reflects the less pronounced correlation between DOC and DON compared to that between POC and PON, although it was still highly significant $\left(\mathrm{r}^{2}=0.7095\right.$, $\mathrm{p}<0.001, \mathrm{n}=72$; Fig. 3). However, DOM and POM were closely related, as shown by the significant correlations between all $\mathrm{C}$ - and $\mathrm{N}$-containing organic matter, with correlation coefficients $\left(\mathrm{r}^{2}\right)$ between 0.6018 and 0.6706 (all data; $\mathrm{n}=72$ to 75 ) (Fig. 3).

Of the nutrients, nitrate and silicate generally followed the signature of salinity (Fig. 2, Table 2). Both nutrients were significantly correlated $\left(\mathrm{r}^{2}=0.7657\right.$, $\mathrm{p}<0.001, \mathrm{n}=80$; Fig. 3). Low concentrations were found in the upper section of the surface ice (lowest in the high-biomass floes) and high concentrations in the gap waters. In the upper section of the surface ice, nitrate was mostly below $1 \mu \mathrm{M}$ in all floes, except for 1 section in the moderate-biomass ice floe $(6.76 \mu \mathrm{M})$. In the bottom section, nitrate was more variable, with values up to 3.6 and $8.1 \mu \mathrm{M}$ in the low- and moderatebiomass floes, respectively. In the bottom section of the high-biomass floe, nitrate was nearly exhausted, with concentrations as low as those in the upper surface ice section. Ratios of silicate to nitrate were higher than in Antarctic seawater (Table 3). The distribution of silicate generally followed that of nitrate, although the former was more variable. In contrast to nitrate, silicate values were not exhausted in the bottom sections of the high-biomass floes.

In the gap waters, nitrate and silicate were highest in the lowbiomass floe, with concentrations of about 27 and $70 \mu \mathrm{M}$, respectively, comparable to surface seawater values in the Weddell Sea in late summer/early autumn (Table 3). With increasing biomass in the gap waters, nitrate decreased to lowest values of $23.3 \mu \mathrm{M}$ in the moderate-biomass and $16 \mu \mathrm{M}$ in the high-biomass floes. The changes in silicate were similar, but again with the exception that in 1 of the high-biomass floes, silicate values were still high although nitrate was considerably reduced.

Phosphate and ammonium were significantly correlated $\left(\mathrm{r}^{2}=0.3270, \mathrm{p}<0.001, \mathrm{n}=80\right)$. However, their distributions were clearly different from those of nitrate and silicate (Figs. $2 \& 3$ ), and neither was correlated with nitrate nor silicate. Concentrations of ammonium and phosphate exceeded seawater concentrations (Table 3) in many of the samples of all floe types. Highest values were found in the bottom section of the high- and moderate-biomass floes, with phosphate and ammonium reaching concentrations of up to 9.08 and $15.6 \mu \mathrm{M}$, respectively. Also in the upper section of the surface ice, ammonium values were higher than usually found in seawater. Phosphate was low in the upper part of the low- and high-biomass floes, but high in the moderate-biomass floe, again showing the high variability between floes. Nitrite was present in all samples, but only in negligible concentrations of $<0.1 \mu \mathrm{M}$ in the ice layers and up to $0.19 \mu \mathrm{M}$ in the gap water.

\section{Floe with surface ice layer and re-frozen gap layer}

On the southernmost floe, ice growth had commenced in the gap from the surface ice layer to the underlying sea ice due to low air temperatures, as described by Fritsen et al. (1994) and Haas et al. (2001). There was virtually no gap water remaining. Dendritic ice had grown from the bottom of the surface ice downwards into the gap water layer below. The surface ice layer was still clearly distinguishable from the underlying sea ice. It had characteristics similar to those from the high-biomass floes (Table 4, Fig. 4). The upper section of the surface ice contained a relatively low algal biomass. In contrast, the underlying bottom section supported extremely high algal standing stocks (see

Table 3. Range of nutrient concentrations in upper mixed layer of the eastern Weddell Sea

\begin{tabular}{|c|c|c|c|c|c|}
\hline Nutrient & Oct/Nov & Dec/Jan & Feb/Mar & Apr/May & Jun/Jul \\
\hline Nitrate $(\mu \mathrm{M})$ & $30.5-31.5^{\mathrm{a}}$ & $31.0^{\mathrm{a}}$ & $23.8-31.5^{\mathrm{b}}$ & $<17^{\mathrm{b}}$ & $24.8-27.7^{\mathrm{c}}$ \\
\hline Silicate $(\mu \mathrm{M})$ & & & $54.9-76.5^{\mathrm{b}}$ & $<50^{\mathrm{b}}$ & $54-62^{\mathrm{c}}$ \\
\hline Ammonium $(\mu \mathrm{M})$ & $0.1-0.7(<0.07)^{\mathrm{a}}$ & & & $0.75-2^{\mathrm{c}}$ & $<0.2^{\mathrm{d}}$ \\
\hline Phosphate $(\mu \mathrm{M})$ & $1.95-2.05^{\mathrm{a}}$ & $2.05-2.15^{\mathrm{a}}$ & $1.8-2.3^{\mathrm{b}}$ & $<1.5^{\mathrm{b}}$ & $1.65-1.95^{c}$ \\
\hline
\end{tabular}


Table 4. Range of particulate and dissolved constituents in surface ice layer of ice floe with re-frozen gap layer

\begin{tabular}{|lcc|}
\hline Constituent & Upper section & Bottom section \\
\hline Salinity & $2.9-10.0$ & $8.0-12.9$ \\
POC $(\mu \mathrm{M} \mathrm{C})$ & $142-579$ & $1070-5667$ \\
PON $(\mu \mathrm{M} \mathrm{N})$ & $17.1-74.1$ & $147-616$ \\
POC/PON & $7.2-10.3$ & $6.1-9.2$ \\
Chl $a\left(\mu \mathrm{g} \mathrm{l}^{-1}\right)$ & $1.2-31.4$ & $172-376$ \\
C/chl a & $107-603$ & $74-217$ \\
DOC $(\mu \mathrm{M} \mathrm{C})$ & $86-507$ & $243-642$ \\
DON $(\mu \mathrm{M} \mathrm{N})$ & $6.5-20.6$ & $25.6-52.6$ \\
DOC/DON & $7.9-20.2$ & $8.2-12.5$ \\
Nitrate $(\mu \mathrm{M})$ & $0.00-1.36$ & $0.06-1.46$ \\
Silicate $(\mu \mathrm{M})$ & $4.03-9.47$ & $15.43-51.3$ \\
Ammonium $(\mu \mathrm{M})$ & $0.23-3.62$ & $5.94-28.40$ \\
Phosphate $(\mu \mathrm{M})$ & $0.12-0.80$ & $0.67-4.42$ \\
\hline
\end{tabular}

photograph in Fig. 1). The bottom ice layers that had formed from the gap layers could be clearly identified by their biogeochemical composition: along the $15 \mathrm{~m}$ long transect from the floe edge to the centre of the floe this bottom-layer section was located between 10 and $20 \mathrm{~cm}$ depth, except for 1 core in which it was $10 \mathrm{~cm}$ deeper. In this layer, POC and PON occurred in concentrations up to about 6000 and $600 \mu \mathrm{M}$, respectively, comparable to concentrations in the bottom section of the high-biomass floes. The highest concentrations were found in the middle of the transect about $7 \mathrm{~m}$ from the floe edge, where the surface ice layer was thinnest. In those sections in which the ice floe was thicker (at the edge and towards the end of the transect), the amount of particulate material was clearly lower. Chl a concentrations and $\mathrm{C} / \mathrm{chl}$ a ratios were also comparable to the high-biomass floe with an open gap.
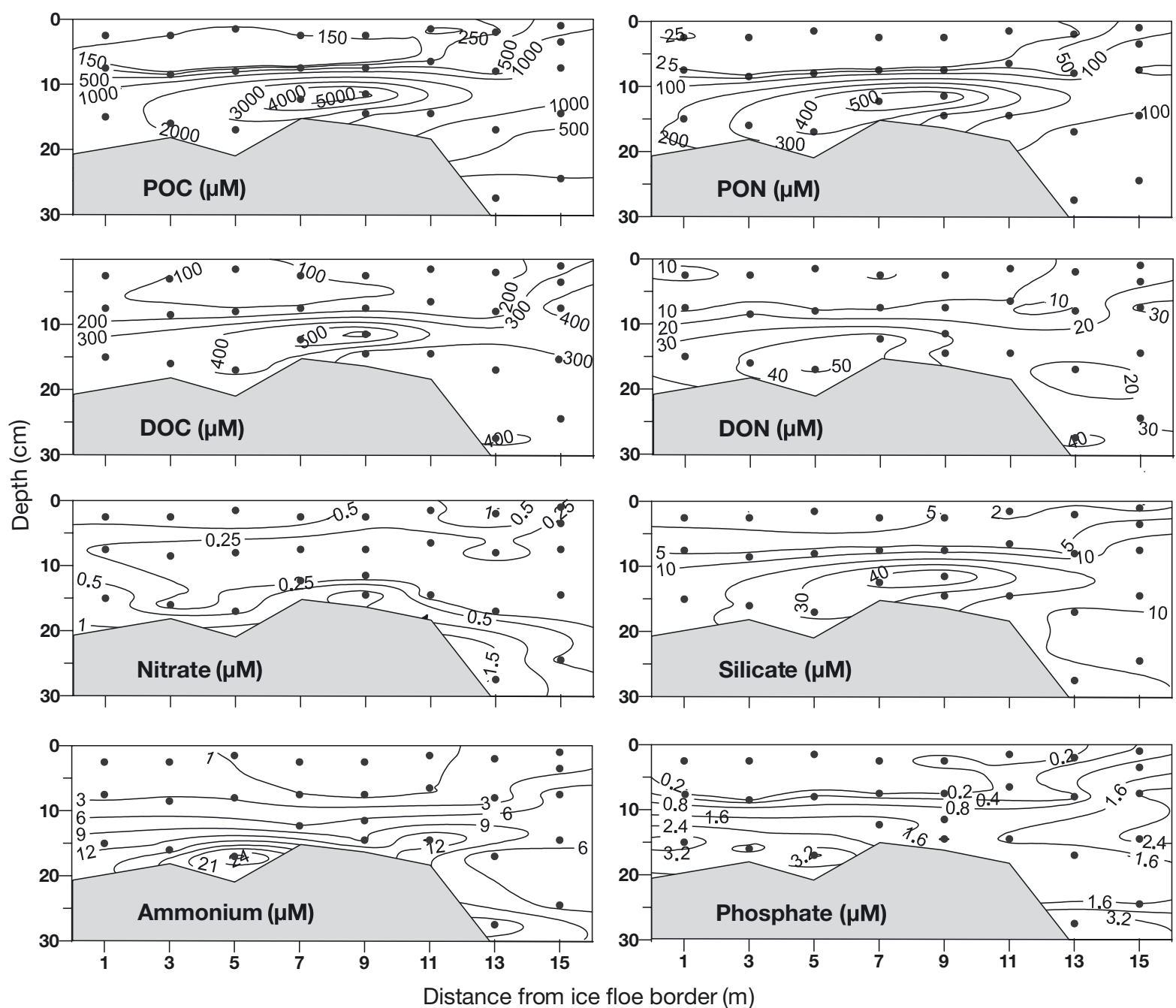

Fig. 4. Distribution of particulate and dissolved organic constituents in surface ice layer of re-frozen gap-layer floe sampled from ice floe edge $(1 \mathrm{~m})$ to middle of floe $(15 \mathrm{~m})$. Shaded area indicates underlying sea ice 
DOC was highest in the biomass-rich bottom sections of the cores (up to $642 \mu \mathrm{M}$ ) but did not reach the high values of the gap-layer floes (up to $1400 \mu \mathrm{M}$ ). In contrast, DON values were similar to all floes with open gaps, varying from 6 to $20 \mu \mathrm{M}$ in the upper section and up to $53 \mu \mathrm{M}$ in the high-biomass bottom section. The location of the DON maximum was slightly shifted from the DOC maximum to the edge of the floe. The DON maximum, however, corresponded to those of ammonium (maximum $28.4 \mu \mathrm{M}$ ) and phosphate $(4.42 \mu \mathrm{M})$, i.e. to the regenerated nutrients (Fig. 4). Concentrations of these nutrients were similar to or even higher than those of the floes with open gaps. $\mathrm{C} / \mathrm{N}$ ratios for both the particulate and dissolved material were also in the same range as for the floes with open gaps.

High silicate concentrations in the re-frozen bottom section (range from 15.4 to $51.3 \mu \mathrm{M}$ ) always coincided with the highest algal biomass, which was clearly different from that of floes with open gaps. These high silicate concentrations in the bottom sections were close to surface seawater values and significantly higher than values that would be normally predicted from dilution processes, which are normal for inorganic nutrients in sea ice. In contrast, in the overlying upper surface section, silicate values ranged from close to zero up to $\sim 8 \mu \mathrm{M}$. This range is similar to that predicted from seawater dilution estimates and similar to those measured in the high-biomass floes with open gaps. The distribution of silicate differed markedly from that of nitrate, which was low throughout all the cores ( 0 to $4.42 \mu \mathrm{M})$ and never reaching the high values $(27 \mu \mathrm{M})$ of the gap waters.

\section{DISCUSSION}

The surface ice layers are mostly composed of superimposed ice formed by re-frozen snow-melt water. However, their bottom sections also consist of snow ice formed by earlier flood-freeze cycles (Ackley \& Sullivan 1994, Fritsen et al. 1994, 1998, 2001, Haas et al. 2001, Maksym \& Jeffries 2001). These processes modify the surface-ice characteristics considerably compared to normal sea ice. Continuous, or at times semi-continuous, horizontal gaps may be partially isolated or, as in the floes studied herein, have direct connections with the surrounding water. Connection with seawater can be horizontal, and exchange of gap waters is enhanced by swell and wave action. Vertical exchange is also possible through the porous and rotten underlying sea ice. This exchange can be very large when the gap waters start to re-freeze, causing unstable conditions in the water column (Fritsen et al. 1994).
The biogeochemistry of floes with open und refreezing gap layers was highly variable. Despite classification into different floe types and ice layers according to biomass and physical factors, the variability remained high. Differences in concentrations by a factor of 6 or even higher were found in some of the parameters for individual ice cores and ice sections from the same floe.

High algal biomass is characteristic of gap layer floes in summer, due to a combination of relatively high levels of irradiance and inorganic nutrient supplies from the surrounding or underlying seawater. It is difficult to estimate residence times or exchange rates of the seawater within the gap water layer, since many factors are responsible for processes of formation of the gaps, as discussed above. Seasonal development will also determine the shape of the gaps and thus exchange with the surrounding water, as reflected by the different productivity of the different ice floes. The depletion of nutrients in the high-biomass floes showed clear uptake by algae within the gap layer and/or algae growing in ice layers in direct contact with gap water. The high concentrations of regenerated nutrients, such as ammonium, also point to a limited exchange with the surrounding seawater. It seems that the nutrient-rich seawater is trapped for a period allowing substantial algal growth although the residence time is not so long that nutrients become exhausted.

Highest biomass accumulated in the bottom section of the surface ice. This may also be enhanced by short freeze-melt cycles due to diurnal solar radiation and air temperature variations. Effectively, this layer immediately overlying the gap water comprises a bottom community in an ice sheet overlying a trapped seawater layer. Clearly, the exchange of inorganic nutrients from the seawater source supports this prolific growth. However, there is evidence from studies on the dynamics of bottom-layer communities that the penetration of nutrient-rich seawater is somewhat poor and that, even within a distance of a few centimetres into the ice, algae assemblages can be severely nutrientlimited (McMinn et al. 1999, Kennedy et al. 2002).

The high concentrations of phosphate and ammonium in the bottom ice layers overlying the gap waters suggest that the high algae standing stock is at least partially maintained by regenerated nutrients, although production is mostly driven by nitrate as nitrogen source, as revealed by the exhaustion of nitrate in the bottom ice layer and the lower values in the gap waters of the high-biomass floes. The POC/PON ratios reflected nutrient-replete ice-algal assemblages throughout all the ice and gap water zones studied herein. The $\mathrm{C} / \mathrm{chl}$ a ratios, a common measure for living phytoplankton communities (Geider et al. 1997), 
were generally below 200, and thus support this finding. The few exceptions of higher ratios were mostly in the upper section of the surface ice. Enhanced ratios of both $\mathrm{C} / \mathrm{chl} a$ and POC/PON, in combination with regeneration of nutrients, however, show that active growth and decay of algae was sometimes occurring simultaneously. This is unusual for marine systems, but indicates that nitrate is not the sole nitrogen source for active algal growth, and that ammonium is actively utilised by ice algae. High ammonium levels may in fact inhibit nitrate uptake within sea ice (Thomas \& Dieckmann 2002b and citations therein).

The diatom-dominated algae community had reduced silicate concentrations in all layers of the biomass-rich floes compared to floes with less algal biomass. However, because of fresh supplies from the surrounding seawater, it is unlikely that silicate will limit diatom growth. There is also potential for regeneration of silicate within the high-biomass environment. Elevated $\mathrm{pH}$ values up to 11 have been recorded within sea ice in which high rates of photosynthesis have depleted $\mathrm{CO}_{2}$ levels and resulted in a higher $\mathrm{pH}$ (Gleitz et al. 1995). $\mathrm{pH}$ values $>9$ will effectively dissolve diatom frustules, or at least increase the rates of diatom dissolution and thus recycle silicate into the system.

Although the upper section of the surface ice layer originated mostly from fresh superimposed ice, it supported high algal biomass in places. This growth was, however, more limited by nutrients (especially by a higher degree of nitrate depletion) than the bottom ice sections, although ammonium as nitrogen source was available in some cores. The elevated POC/PON and $\mathrm{C} / \mathrm{chl}$ a ratios with increasing biomass also indicated a nutrient limitation of the algae growing in this zone of the ice. Enhanced concentrations of nutrients in the upper part of the surface ice layers may be the result of more recent seawater flooding the ice surface; this occurred particularly at the end of the summer season (Haas et al. 2001). Upward flushing of seawater from the gap below is more unlikely, since the superimposed ice layers are fairly impermeable.

The low biomass in the gap waters of the highbiomass floes compared to the moderate-biomass floe was probably due to higher exchange rates of the seawater in the former. Later in the summer, flushing through gap layers may increase, since these are then larger than in early summer. On the other hand, reduced nutrient concentrations in this water must result from an increased and faster uptake by ice algae growing at the bottom ice layer. The generally low POC/PON and $\mathrm{C} / \mathrm{chl}$ a ratios in the gap water of all floes point to an actively growing algae community, and the algae concentrations within these gap waters are far in excess of those concentrations found in surface waters outside the ice floes.
In most samples, particulate organic matter concentration was higher than that of dissolved organic matter, reflecting the high biomass production in the ice layers. However, in some samples, the levels of DOM were exceedingly high, and DOC and DON concentrations over $1.3 \mathrm{mM}$ and $60 \mu \mathrm{M}$, respectively, were among the highest reported for sea-ice habitats (Thomas et al. 2001). The POC/PON ratios lay in a relatively small range between 6 and 12 and were often lower than the DOC/DON ratios which showed a higher degree of variability and patchiness. The wider range in $\mathrm{C} / \mathrm{N}$ ratios of the dissolved organic matter (which is typical for sea ice systems; Thomas et al. 2001) reflects its many sources: from freshly decaying or even actively released material to material already degraded by bacteria. Feeding of zooplankton on ice algae may also cause a relative decrease in the proportion of DON due to release of ammonium. This is supported by the considerable amounts of ammonium recorded, especially in the ice floes with higher algal biomass, and by the fact that high numbers of copepods were grazing in gap layers (Schnack-Schiel et al. 2001).

DOC/DON ratios, which were higher than POC/ PON ratios, were measured in all types of ice sampled, but particularly within the high-biomass and the refrozen gap-layer floes. POC/PON ratios between 6 and 12 indicate that the algal biomass in these floes was mostly actively growing. However, $\mathrm{C} / \mathrm{chl}$ a ratios were more variable, reflecting both growth as well as decay or degradation of particulate material. The higher DOC/DON ratios may result from a greater rate of release of nitrogen from the DOM pool, or may reflect high amounts of carbon-rich polysaccharide material excreted by sea-ice algae and bacteria (Herborg et al. 2001). Much of this material is produced in the form of transparent extracellular polymeric particles that have been found in high concentrations within Arctic and Antarctic sea ice (Krembs et al. 2002, Meiners 2002, Meiners et al. 2003). Junge et al. (2001) and Krembs et al. (2002) raised the possibility of such polymeric material being produced to protect cells from freezing damage; if true, high levels would be expected to be produced within the recently frozen gap layer.

In addition, physical processes will also control the concentrations of DOM within the ice, since during freezing DOM will be lost to the underlying water (together with other dissolved constituents) as brine expelled from the growing-ice phase (Giannelli et al. 2001). This may account for the fact that DOM levels in the re-frozen gaps were considerably lower than those in the bottom sections of the other surface ice layers sampled during this study.

Of interest is that the DOC maximum in the floe with the re-frozen gap layer was slightly displaced from the 
DON maximum (Fig. 4). However, DOC and DON were still highly significantly correlated $\left(\mathrm{r}^{2}=0.8136\right.$, $\mathrm{p}<0.001, \mathrm{n}=31$ ) in this floe. The fact that ammonium and phosphate maxima occurred simultaneously with the DON peak points to bacterial activity causing spatial heterogeneity and a slight decoupling of DOM dynamics within a relatively small spatial scale. It has been speculated that there may be an uncoupling of DOC and DON metabolism within ice systems (Thomas et al. 1995); this was not supported by the results of our study. The generally very close relationships between particulate and dissolved organic matter as well as between nitrate and silicate emphasise that the habitats of gap-layer ice floes are semienclosed ecosystems and that this holds true when the gaps start to re-freeze. The high concentrations of the regenerated nutrients ammonium and phosphate and their significant correlation further point to a partially enclosed system in which the residence time of seawater (which can be flushed in from the edge or from the underside of the floe) is long enough to sustain the extraordinary high biomasses in a unique ecosystem that is only found during the melting process of perennial ice during summer.

The combination of a solid bottom layer with a continuous supply of nutrients and relatively little light limitation close to the ice surface are the reason for the high biomass and the high values of dissolved organic substances found in this study. These are among the highest values ever reported for Antarctic pack-ice (cf. Brierley \& Thomas 2002 and citations therein). One of the most striking features of this study was the high degree of spatial variability in algal biomass and chemical parameters within a single floe. This highlights one of the main problems facing sea-ice biogeochemical studies, and the interpretation of processes occurring within sea ice. Clearly much of this heterogeneity is governed by the high degree of physical variability within an ice floe. Most sea ice studies have to rely on spot measurements from single-core samples. Systematic studies are needed to further investigate the variability within single floes and between floes across wide geographic areas. The logistics of such studies are complicated and not easily tenable, but the validation of sea ice models, especially for the prediction of sea ice primary production and the role of sea ice in air-ocean exchange processes will increasingly depend on us understanding the variation within sea ice habitats, especially in the highly productive surface systems.

Despite the sampling problems, it is very likely that surface-ice habitats play a major role in sea ice primary productivity during summer in most sea ice regions of the Southern Ocean, since flood-freeze cycles and the occurrence of superimposed ice are widespread, as also reported for the Bellingshausen, Amundsen and Ross Seas and East Antarctica (Jeffries et al. 1997, Kawamura et al. 1997, Haas et al. 2001).

Acknowledgements. We would like to thank the captain and crew of the RV 'Polarstern', the pilots and crew of the 'Wasserthal' helicopter service, and J. Bareiss for vital help in the field. We thank P. Kennedy, J. Anderson (Bangor) and M. Wolff (Bremerhaven) for their help in the analytical work. The work was partially funded by NERC grants GT9/2894 and GR9/3309, The British Council/DAAD (ARC Programme), The Nuffield Foundation, The Royal Society (Joint Project) and the Hanse Institute of Advanced Study.

\section{LITERATURE CITED}

Ackley SF, Sullivan CW (1994). Physical controls on the development and characteristics of Antarctic sea ice biological communities - a review and synthesis. Deep-Sea Res 41:1583-1604

Arrigo KR (2003) Primary production in sea ice. In: Thomas DN, Dieckmann GS (eds) Sea ice-an introduction to its physics, chemistry, biology and geology. Blackwell, Oxford, p 143-183

Brierley AS, Thomas DN (2002) The ecology of Southern Ocean pack ice. Adv Mar Biol 43:171-278

Dieckmann GS, Hellmer HH (2003) The importance of sea ice: an overview. In: Thomas DN, Dieckmann GS (eds) Sea ice-an introduction to its physics, chemistry, biology and geology. Blackwell, Oxford, p 1-21

Eicken H, Lange MA, Hubberten HW, Wadhams P (1994) Characteristics and distribution patterns of snow and meteoric ice in the Weddell Sea and their contribution to the mass balance of sea ice. Ann Geophysicae 12:80-93

Evans CA, O'Reilly JE, Thomas JP (1987) A handbook for the measurement of chlorophyll a and primary production. BIOMASS Handbook 8. Texas A\&M Univ, College Station, TX

Fahl K, Kattner G (1993) Lipid content and fatty acid composition of algal communities in sea ice and water from the Weddell Sea (Antarctica). Polar Biol 13:405-409

Fritsen CH, Lytle VI, Ackley SF, Sullivan CW (1994) Autumn bloom of Antarctic pack-ice algae. Science 266:782-784

Fritsen CH, Ackley SF, Kremer JN, Sullivan CW (1998) Flood-freeze cycles and microalgal dynamics in Antarctic pack ice. Antarct Res Ser 73:1-21

Fritsen CH, Coale SL, Neenan DR, Gibson AH, Garrison DL (2001) Biomass, production and microhabitat characteristics near the freeboard of ice floes in the Ross Sea, Antarctica, during the austral summer. Ann Glaciol 33: 280-286

Garrison DL, Buck KR (1991) Surface-layer sea ice assemblages in Antarctic pack ice during the austral spring: environmental conditions, primary production and community structure. Mar Ecol Prog Ser 75:161-172

Garrison DL, Mathot S (1996) Pelagic and sea ice microbial communities. Antarct Res Ser 70:155-172

Garrison DL, Jeffries MO, Gibson A, Coale SL, Neenan D, Fritsen C, Okolodkov YB, Gowing MM (2003) Development of sea ice microbial communities during autumn ice formation in the Ross Sea. Mar Ecol Prog Ser 259:1-15

Geider RJ, MacIntyre HL, Kana TM (1997) Dynamic model of phytoplankton growth and acclimation: response of the balanced growth rate and the chlorophyll a:carbon ratio to light, nutrient-limitation and temperature. Mar Ecol Prog Ser 148:187-200 
Giannelli V, Thomas DN, Haas C, Kattner G, Kennedy HA, Dieckmann GS (2001) Behaviour of dissolved organic matter and inorganic nutrients during experimental sea ice formation. Ann Glaciol 33:317-321

Gleitz M, Bathmann UV, Lochte K (1994) Build-up and decline of summer phytoplankton biomass in the eastern Weddell Sea, Antarctica. Polar Biol 14:413-422

Gleitz M, Rutgers van der Loeff MM, Thomas DN, Dieckmann GS, Millero FJ (1995) Comparison of summer and winter inorganic carbon, oxygen and nutrient concentrations in Antarctic sea ice brine. Mar Chem 51:81-91

Haas C, Thomas DN, Steffens M, Bareiss J (1998) Physical and biological investigations of sea ice. Ber Polarforsch $267: 18-30$

Haas C, Thomas DN, Bareiss J (2001) Surface properties and processes of perennial Antarctic sea ice in summer. J Glaciol 47:613-625

Herborg LM, Thomas DN, Kennedy H, Haas C, Dieckmann GS (2001) Dissolved carbohydrates in Antarctic sea ice. Antarct Sci 13:119-125

Jeffries MO, Worby AP, Morris K, Weeks WF (1997) Seasonal variations in the properties and structural composition of sea ice and snow cover in the Bellingshausen and Amundsen seas, Antarctica. J Glaciol 43:138-151

Junge K, Krembs C, Deming J, Stierle A, Eicken H (2001) A microscopic approach to investigate bacteria under in-situ conditions in sea-ice samples. Ann Glaciol 33:304-310

Kattner G (1999) Storage of dissolved inorganic nutrients in seawater: poisoning with mercuric chloride. Mar Chem 67:61-66

Kattner G, Becker H (1991) Nutrients and organic nitrogenous compounds in the marginal ice zone of Fram Strait. J Mar Syst 2:385-394

Kawamura T, Ohshima KI, Takizawa T, Ushio S (1997) Physical, structural, and isotopic characteristics and growth processes of fast sea ice in Lützow-Holm Bay, Antarctica. J Geophys Res C 102:3345-3355

Kennedy H, Thomas DN, Kattner G, Haas C, Dieckmann GS (2002) Particulate organic matter in Antarctic summer sea ice: concentrations and stable isotopic composition. Mar Ecol Prog Ser 238:1-13

Koroleff F (1983) Total and organic nitrogen. In: Grasshoff K, Erhardt M, Kremling K (eds) Methods of seawater analysis. Verlag Chemie, Weinheim, p 162-173

Krembs C, Eicken H, Junge K, Deming JW (2002) High concentrations of exopolymeric substances in Arctic winter sea ice: implications for the Polar ocean carbon cycle and cryoprotection of diatoms. Deep-Sea Res I 49:2163-2181

Leventer A (2003) Particulate flux from sea ice in Polar waters. In: Thomas DN, Dieckmann GS (eds) Sea ice-an introduction to its physics, chemistry, biology and geology. Blackwell, Oxford, p 303-332

Lizotte MP (2001) The contributions of sea ice algae to Antarctic marine primary production. Am Zool 41:57-73

Editorial responsibility: Otto Kinne (Editor),

Oldendorf/Luhe, Germany
Maksym T, Jeffries MO (2001) Phase and compositional evolution of the flooded layer during snow-ice formation on Antarctic sea ice. Ann Glaciol 33:37-44

Massom RA, Eicken H, Haas C, Jeffries MO and 10 others (2001) Snow on Antarctic Sea ice. Rev Geophys 39: 413-445

McMinn A, Skerratt J, Trull T, Ashworth C, Lizotte M (1999) Nutrient stress gradient in the bottom $5 \mathrm{~cm}$ of fast ice, McMurdo Sound, Antarctica. Polar Biol 21:220-227

Meiners K (2002) Sea-ice communities: structure and composition in Baltic, Antarctic and Arctic Seas. PhD thesis, University of Kiel, Germany

Meiners K, Gradinger R, Fehling J, Civitarese G, Spindler M (2003) Vertical distribution of exopolymer particles in sea ice of the Fram Strait (Arctic) during autumn. Mar Ecol Prog Ser 248:1-13

Nöthig EM, Bathmann U, Jennings JC, Fahrbach E, Gradinger R, Gordon LI, Makarov R (1991) Regional relationships between biological and hydrographical properties in the Weddell Gyre in late austral winter 1989. Mar Chem 35:325-336

Qian J, Mopper K (1996) Automated high-performance, hightemperature combustion total carbon analyzer. Anal Chem 68:3090-3097

Scharek R (1991) Development of phytoplankton during the late-winter/spring transition in the eastern Weddell Sea (Antarctica). Ber Polarforsch 94:195

Schnack-Schiel SB, Thomas DN, Haas C, Dieckmann GS, Alheit R (2001) The occurrence of the copepods Stephos longipes (Calanoida) and Drescheriella glacialis (Harpacticoida) in summer sea ice in the Weddell Sea. Antarct Sci 13:150-157

Syvertsen EE, Kristiansen S (1993) Ice algae during EPOS leg 1: assemblages, biomass, origin and nutrients. Polar Biol 13:61-65

Thomas DN, Dieckmann GS (2002a) Antarctic sea ice-a habitat for extremophiles. Science 295:641-644

Thomas DN, Dieckmann, GS (2002b) Biogeochemistry of Antarctic sea ice. Oceanogr Mar Biol Annu Rev 40: 143-169

Thomas DN, Lara RJ, Eicken H, Kattner G, Skoog A (1995) Dissolved organic matter in Arctic multi-year sea ice during winter: major components and relationship to ice characteristics. Polar Biol 15:477-483

Thomas DN, Lara RJ, Haas C, Schnack-Schiel SB, Nöthig EM, Dieckmann GS, Kattner G, Mizdalski E (1998) Biological soup within decaying summer sea ice in the Amundsen Sea, Antarctica. Antarct Res Ser 73:161-171

Thomas DN, Kattner G, Engbrodt R, Giannelli V, Kennedy H, Haas C, Dieckmann GS (2001) Dissolved organic matter in Antarctic sea ice. Ann Glaciol 33:297-303

Wedborg M, Hoppema M, Skoog A (1998) On the relationship between organic and inorganic carbon in the Weddell Sea. J Mar Syst 17:59-76

Submitted: January 29, 2004; Accepted: May 4, 2004

Proofs received from author(s): August 6, 2004 